\title{
Energy Efficiency Classification of Agricultural Tractors in Korea
}

\author{
Chang Seop Shin ${ }^{1}$ Kyeong Uk Kim ${ }^{1,2^{*}}$, Kwan Woo Kim ${ }^{3}$ \\ ${ }^{1}$ Department of Biosystems and Biomaterial Science and Engineering, Seoul National University, Seoul, Korea \\ ${ }^{2}$ Research Institute for Agriculture and Life Sciences, Seoul National University, Seoul, Korea \\ ${ }^{3}$ Foundation of Agricultural Technology Commercialization and Transfer, Suwon, Korea
}

Received: July 29 $9^{\text {th }}, 2012$; Revised: August $21^{\text {th }}, 2012$; Accepted: August $31^{\text {th }}, 2012$

\section{Abstract}

Purpose: This study was conducted to classify the energy efficiency of 131 tractor models tested during from 2006 to 2010 in Korea. Methods: Four sub-indexes were developed using the fuel consumptions at $60 \%$ and $90 \%$ of rated speed with partial loads and at pull speeds of $3.0 \mathrm{~km} / \mathrm{h}$ and $7.5 \mathrm{~km} / \mathrm{h}$ with maximum drawbar pull. Weighting factors of the sub-indexes were also considered to reflect the characteristics of tractor's actual working hours in Korea. Four sub-indexes were integrated into a classification index. Using the developed classification index, a five-classification system was made on the basis of normal distribution of tractors over the classification range. Percentage of $1^{\text {st }}$ grade interval was expected to be close to $15 \%, 2^{\text {nd }}$ grade $20 \%, 3^{\text {rd }}$ grade $30 \%, 4^{\text {th }}$ grade $20 \%, 5^{\text {th }}$ grade $15 \%$. Results: Number of $1^{\text {st }}$ grade was $21,2^{\text {nd }}$ grade 23 , $3^{\text {rd }}$ grade $39,4^{\text {th }}$ grade $33,5^{\text {th }}$ grade 15 among 131 models. Conclusions: Classification index was developed by integrating four sub-indexes. By the classification method using developed index, distribution of classified tractors was acceptable for practical application.

Keywords: Agricultural tractor, Classification Index, Energy efficiency

\section{Introduction}

The number of agricultural tractors sold in Korea has been increasing during the period from 2005 to 2010 (e.g. 10,121 units in 2005 and 13,891 units in 2010). The total number of agricultural tractors used in Korea was 267,871 in 2011(MIFAFF, 2011). Fossil fuel consumed by agricultural tractors in Korea is increasing as the increase of tractors.

Saving energy has become a big issue throughout the world. Many countries have legislated effective energy saving. Classification of energy efficiency is an indirect way to reduce fuel consumption. Grading energy efficiency of products can provide customers with the information on decision-making. To implement energy efficiency classification to agricultural tractors is very important

\footnotetext{
*Comesponding author: Kyeong-Uk Kim

Tel: +82-2-880-46; Fax: +82-2-873-2049

E-mail: kukim@snu.ac.kr
}

from the energy saving perspectives. The classification of agricultural tractors by energy efficiency has been introduced in foreign countries. In Spain, based on OECD 1 and 2, classification index was developed using fuel consumption and power data, and 214 tractor models were classified by those indexes (Gil-Sierra et al, 2007). In France, classification of agricultural tractors by energy efficiency was carried out by joint scientific work of Spain and France(OECD, 2009). In Turkey, 55 tractor models were classified by seven-classification system.(OECD, 2012).

In Korea, research for the classification of agricultural tractors by energy efficiency has begun recently. Equation to predict fuel consumption for partial loads at non-rated speeds was developed and five-classification method using a certain index was suggested (Kim et al., 2010).

To implement energy efficiency classification, a classification index should be developed based on the fuel consumption data. The test report on OECD tractor can 
provide reasonable data for Korean tractors. However, since Korean test procedure is not the same as OECD one, we need to develop new one for Korean tractors.

This paper presents an index development procedure based on Korean agricultural tractors test reports and a five-classification method was developed for energy efficiency classification procedure.

\section{Materials and Methods}

\section{Available data}

There are different methods between OECD and Korean ones. Unlike the OECD test, Korean test method follows Korean version. Among the test procedure the available codes were selected. Table 1 compare the OECD test method and Korean one to develop classification index.

\section{Index zones}

Four zones in OECD tractor test report were chosen to develop a classification index (Table 2).

\section{Sub-index $C_{\text {rate }}$}

Five operational points in the rated speed zone were chosen from the torque curve (Figure 1). and the sub-index $C_{\text {rate }}$ was defined as the average value of specific volumetric fuel consumption (SVFC) over all points.

$$
\begin{aligned}
C_{\text {rate }}= & \frac{1}{5}\left(S V F C_{1}+S V F C_{2}+S V F C_{3}\right. \\
& \left.+S V F C_{4}+S V F C_{5}\right) \\
= & \frac{1}{5} \sum_{i=1}^{5} \frac{Q_{i}}{P_{i}}
\end{aligned}
$$

where,$P_{i}=$ power at point i, i =1, 2, 3, 4, $5(\mathrm{~kW})$

$$
Q_{i}=\text { fuel consumption at point } \mathrm{i}(\mathrm{L} / \mathrm{h})
$$

\section{Sub-index $C_{P T O}$}

Similarly, sub-index $C_{P T O}$ can be obtained using the fuel consumption data at the five operational points in the

\begin{tabular}{|c|c|c|c|}
\hline Test & OECD CODE 2 & Domestic & Available data \\
\hline \multirow{4}{*}{ Main power take-off } & Maximum power test & included & \multirow{6}{*}{$\begin{array}{l}\text { engine speed }\left(\min ^{-1}\right) \text {, } \\
\text { power }(\mathrm{kW}) \\
\text { fuel consumption }(\mathrm{L} / \mathrm{h})\end{array}$} \\
\hline & Test at full load and varying speed & included & \\
\hline & at rated engine speed & included & \\
\hline & $\begin{array}{l}\text { at standard power take-off speed } \\
\left.\text { [540 or } 1000 \mathrm{~min}^{-1}(\mathrm{rev} / \mathrm{min})\right]\end{array}$ & not included & \\
\hline Fuel consumption tests & $\begin{array}{l}\text { Tests at varying load at five extra points for } \\
\text { calculating fuel consumption characteristics }\end{array}$ & not included & \\
\hline $\begin{array}{l}\text { Drawbar power and fuel } \\
\text { consumption test, } \\
\text { unballasted tractor }\end{array}$ & $\begin{array}{l}\text { The power available at the drawbar } \\
\text { of the unballasted tractor over a range of different } \\
\text { gears/speed settings }\end{array}$ & included & \\
\hline
\end{tabular}

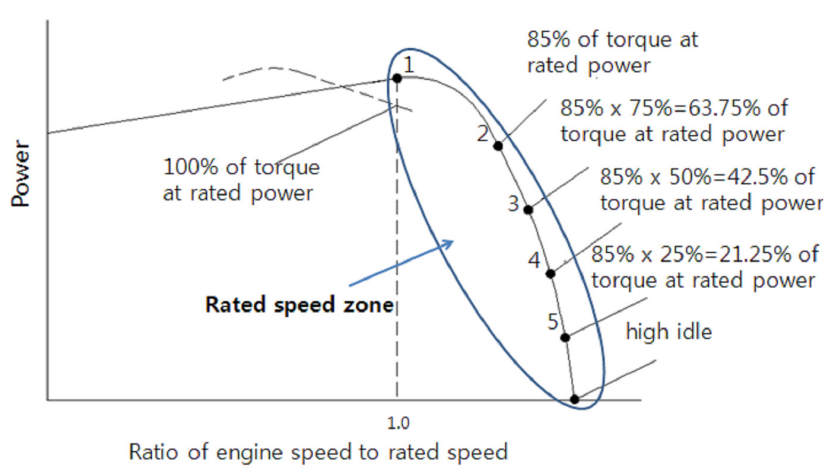

Figure 1. Five operational points for sub-index $C_{\text {rate }}$.

\section{Table 1. OECD test vs. Korean test}

\section{Table 2. Four Zones for developing classification index}

\begin{tabular}{cl} 
Name of Zone & Meaning of Zone \\
Rated speed & Varying load at rated engine speed with full throttle \\
Standard PTO speed & Varying load at standard PTO speed with full throttle \\
Non-rated speed & Partial load at reduced speeds with reduced throttle \\
Drawbar & Drawbar performance at pull speeds of $3.0 \mathrm{~km} / \mathrm{h}$ and $7.5 \mathrm{~km} / \mathrm{h}$ \\
\hline
\end{tabular}




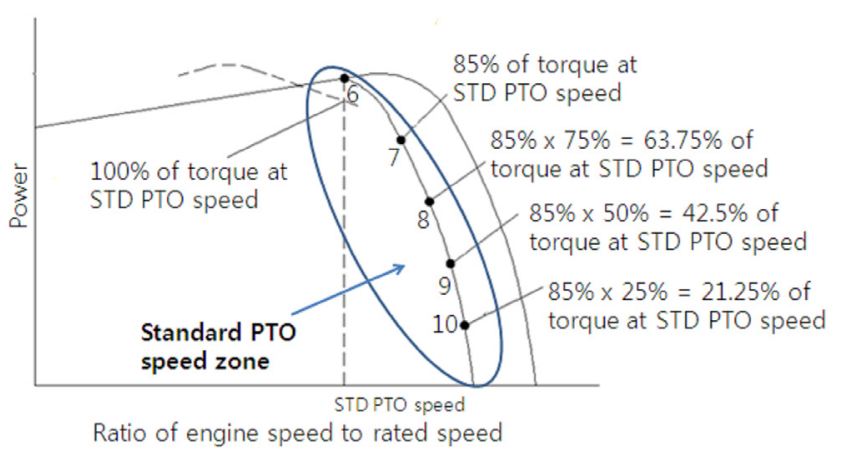

Figure 2. Five operational points for sub-index $C_{P T O}$.

varying load test at the standard PTO speed (Figure 2).

Using power and fuel consumption data, the sub-index $C_{P T O}$ can be determined by equation (2).

$$
C_{P T O}=\frac{1}{5}\left(\frac{Q_{6}}{P_{6}}+\frac{Q_{7}}{P_{7}}+\frac{Q_{8}}{P_{8}}+\frac{Q_{9}}{P_{9}}+\frac{Q_{10}}{P_{10}}\right)
$$

\section{Sub-index $C_{P A R T}$}

Fuel consumption data from the OECD tractor test reports were used for four partial load points from 13 to 16 (Figure 3), because there are no available data in Korean ones, and these data were employed to use Kim's model (Kim et al., 2011). Similarly, using the fuel consumption data at four partial load points and adding two more points (11 and 12) which represent the maximum rated power, sub-index $C_{P A R T}$ can be calculated as equation (3). It should be noted that the specific volumetric fuel consumptions at the partial load are weighted twice than those at the maximum rated power to reflect the usage characteristics of tractors in Korea.

$$
\begin{aligned}
C_{P A R T} & =\frac{1}{10}\left(\sum_{i=11}^{12} S V F C_{i}+2 \times \sum_{i=13}^{16} S V F C_{i}\right) \\
& =\frac{1}{10}\left(\sum_{i=11}^{12} \frac{Q_{i}}{P_{i}}+2 \times \sum_{i=13}^{16} \frac{Q_{i}}{P_{i}}\right)
\end{aligned}
$$

where, $P_{i}=$ power at point i, i $=11,12,13,14,15,16(\mathrm{~kW})$

$Q_{i}=$ fuel consumption at point i, i $=11,12,13$, $14,15,16(\mathrm{~L} / \mathrm{h})$

\section{Sub-index $C_{P U L L}$}

Rotovating and plowing take two most large portions of drawbar work in tractors used in Korea. Average working speeds of these two operations are generally known to be

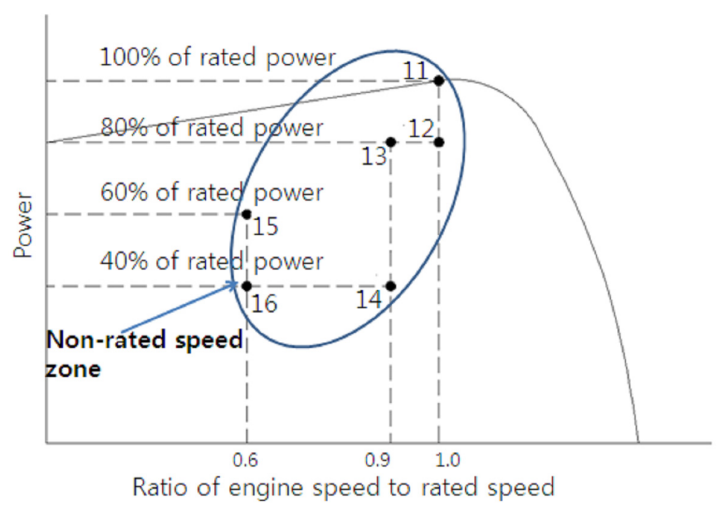

Figure 3. Six operational points for sub-index $C_{P A R T}$.

around $3.0 \mathrm{~km} / \mathrm{h}$ and $7.5 \mathrm{~km} / \mathrm{h}$ respectively(Kim et al, 2010). Sub-index $C_{P U L L}$ was determined using the fuel consumption data at pull speeds $(3.0 \mathrm{~km} / \mathrm{h}$ and $7.5 \mathrm{~km} / \mathrm{h})$ in drawbar performance test (Table 3). These data are also available from the OECD tractor test reports. Equation (4) gives the sub-index $C_{P U L L}$.

$$
C_{P U L L}=\frac{1}{2}\left(\frac{Q_{3.0}}{P_{3.0}}+\frac{Q_{7.5}}{P_{7.5}}\right)
$$

where, $Q_{3.0}, P_{3.0}=$ fuel consumption and drawbar power at close to $3.0 \mathrm{~km} / \mathrm{h}$

$Q_{7.5}, P_{7.5}=$ fuel consumption and drawbar power at close to $7.5 \mathrm{~km} / \mathrm{h}$

\section{Prediction in standard PTO speed zone}

In standard PTO speed zone, both power and fuel consumption should be predicted because there are no data available at standard PTO speed in Korean test report. Point 6 is the point at the standard PTO speed (Figure 4). In addition, in non-rated speed zone, fuel consumption data also should be predicted.

In the Korean test report, since power and fuel consumption data were only available at point 6 in standard PTO speed zone, ones at points from 7 to 10 were predicted for further processing.

At first, power was predicted using both power data at the standard PTO speed and power ratios of four operational points at rated speed zone (equation (5)).

$$
P_{i}=P_{6} \times \frac{P_{i-5}}{P_{1}} \quad(i=7,8,9,10)
$$

Then, the fuel consumption at the standard PTO speed 


\begin{tabular}{|c|c|c|c|c|c|c|c|c|c|c|c|c|c|}
\hline \multirow{3}{*}{$\begin{array}{l}\text { number of } \\
\text { speed } \\
\text { changing } \\
\text { step } \\
\text { [main-sub } \\
\text { (step)] } \\
\text { A-1 }\end{array}$} & \multirow[b]{2}{*}{$\begin{array}{c}\text { power } \\
\text { (kW) }\end{array}$} & \multirow{2}{*}{$\begin{array}{l}\text { tractive } \\
\text { force } \\
(\mathrm{kN})\end{array}$} & \multirow{2}{*}{$\begin{array}{c}\text { pull } \\
\text { speed } \\
(\mathrm{km} / \mathrm{h})\end{array}$} & \multirow{2}{*}{$\begin{array}{l}\text { engine } \\
\text { rpm } \\
\text { (rpm) }\end{array}$} & \multirow{2}{*}{$\begin{array}{l}\text { wheel } \\
\text { slip } \\
(\%)\end{array}$} & \multirow{2}{*}{$\begin{array}{c}\text { specific } \\
\text { volumetric } \\
\text { fuel } \\
\text { consumption } \\
(\mathrm{g} / \mathrm{kW} \cdot \mathrm{h})\end{array}$} & \multirow[b]{2}{*}{$\begin{array}{c}\text { specific } \\
\text { energy } \\
(\mathrm{kW} \cdot \mathrm{h} / \mathrm{L})\end{array}$} & \multicolumn{3}{|c|}{ temperature } & \multicolumn{3}{|c|}{ ambient condition } \\
\hline & & & & & & & & $\begin{array}{l}\text { fuel } \\
\left({ }^{\circ} \mathrm{C}\right)\end{array}$ & $\begin{array}{c}\text { coolant } \\
\left({ }^{\circ} \mathrm{C}\right)\end{array}$ & $\begin{array}{l}\text { engine } \\
\text { oil } \\
\left({ }^{\circ} \mathrm{C}\right)\end{array}$ & $\begin{array}{c}\text { outdoor } \\
\text { tempera-ture } \\
\left({ }^{\circ} \mathrm{C}\right)\end{array}$ & $\begin{array}{c}\text { relative } \\
\text { humidity } \\
(\%)\end{array}$ & $\begin{array}{c}\text { air } \\
\text { press-ure } \\
(\mathrm{kPa})\end{array}$ \\
\hline & 14.01 & 34.31 & 1.47 & 2432 & 15.0 & 691 & 1.210 & 22 & 80 & 96 & 11 & 50 & 100.9 \\
\hline A-2 & 16.52 & 33.66 & 1.77 & 2422 & 15.1 & 632 & 1.323 & 24 & 80 & 96 & 11 & 51 & 100.9 \\
\hline A-3 & 20.12 & 34.50 & 2.10 & 2412 & 15.0 & 538 & 1.555 & 24 & 80 & 97 & 11 & 52 & 100.9 \\
\hline A-4 & 24.48 & 34.43 & 2.56 & 2395 & 15.0 & 506 & 1.651 & 24 & 81 & 97 & 11 & 53 & 100.9 \\
\hline B-1 & 33.63 & 34.04 & 3.56 & 2377 & 15.1 & 407 & 2.056 & 25 & 80 & 97 & 11 & 53 & 100.9 \\
\hline B-2 & 39.97 & 34.37 & 4.19 & 2354 & 15.0 & 371 & 2.256 & 25 & 81 & 97 & 11 & 52 & 100.9 \\
\hline B-3 & 47.83 & 34.83 & 4.94 & 2323 & 15.0 & 341 & 2.449 & 25 & 81 & 98 & 12 & 51 & 100.9 \\
\hline C-1 & 51.64 & 34.43 & 5.40 & 2251 & 15.0 & 332 & 2.520 & 25 & 80 & 98 & 12 & 50 & 100.9 \\
\hline B-4 & 53.15 & 34.49 & 5.55 & 2126 & 15.0 & 327 & 2.555 & 25 & 81 & 97 & 12 & 49 & 100.9 \\
\hline C-2 & 55.71 & 34.09 & 5.88 & 2027 & 15.0 & 314 & 2.667 & 25 & 80 & 98 & 12 & 49 & 100.9 \\
\hline C-3 & 59.21 & 31.47 & 6.77 & 1903 & 12.6 & 299 & 2.794 & 25 & 80 & 98 & 13 & 49 & 100.9 \\
\hline D-1 & 59.65 & 26.97 & 7.96 & 1902 & 9.8 & 296 & 2.821 & 26 & 81 & 98 & 12 & 49 & 100.9 \\
\hline C-4 & 59.70 & 24.65 & 8.72 & 1907 & 8.7 & 294 & 2.845 & 26 & 81 & 99 & 12 & 48 & 100.9 \\
\hline D-2 & 61.40 & 22.38 & 9.88 & 1903 & 7.4 & 290 & 2.888 & 26 & 82 & 99 & 12 & 49 & 100.9 \\
\hline D-3 & 62.14 & 18.56 & 12.05 & 1903 & 5.5 & 284 & 2.941 & 26 & 81 & 99 & 13 & 49 & 100.9 \\
\hline$E-1$ & 61.39 & 16.08 & 13.74 & 1907 & 4.7 & 287 & 2.909 & 26 & 80 & 99 & 13 & 48 & 100.9 \\
\hline D-4 & 59.32 & 14.21 & 15.03 & 1904 & 3.9 & 298 & 2.802 & 26 & 80 & 99 & 13 & 47 & 100.9 \\
\hline E-2 & 59.67 & 12.84 & 16.73 & 1905 & 3.6 & 299 & 2.798 & 26 & 82 & 100 & 13 & 48 & 100.9 \\
\hline
\end{tabular}

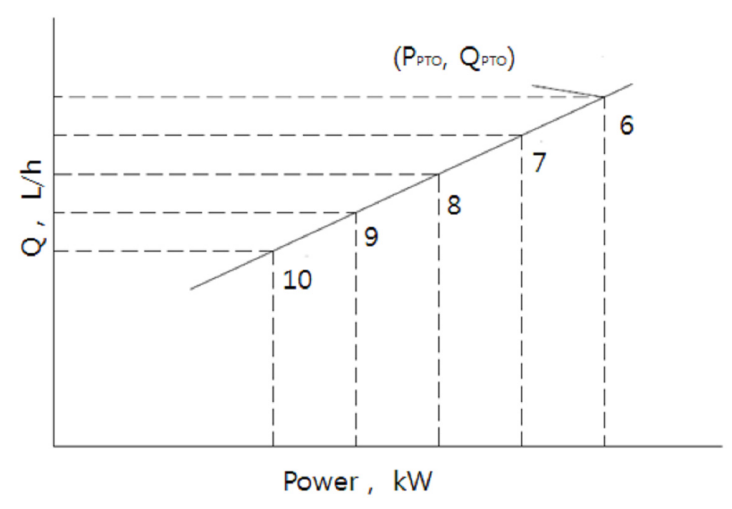

Figure 4. Fuel consumption vs. power at five operational points.

zone was predicted by equation (6). The slope of the regression line correlating the fuel consumption and power, which are predicted at five operational points in standard PTO speed zone in Figure 2, is the same as the regression line for five operational points in rated speed zone like Figure $4 . \mathrm{P}_{\mathrm{P} \text { то }}$ and $\mathrm{Q}_{\mathrm{PTo}}$ were defined as the power and fuel consumption at the standard PTO speed.

Varying load at the standard PTO speed, the slope of the regression line of fuel consumption versus power is the same as the regression line of varying load at the rated speed.

$$
Q_{i}=a\left(P_{i}-P_{P T O}\right)+Q_{P T O}
$$

where, $\mathrm{a}=$ slope of fuel consumption vs. power curve at the rated engine speed with varying load $(\mathrm{L} / \mathrm{kWh})$

$P_{i}=$ power at point i, i $=7,8,9,10(\mathrm{~kW})$

$Q_{i}=$ fuel consumption at point i, i $=7,8,9,10$

$$
(\mathrm{L} / \mathrm{h})
$$

$P_{\text {PTO }}=$ power at standard PTO speed $(\mathrm{kW})$

$Q_{P T O}=$ fuel consumption at standard PTO speed

$$
\text { (L/h) }
$$

This prediction equation is based on the assumption that the slope of regression line of fuel consumption vs. power at standard PTO speed zone is the same as at the rated speed zone. 


\section{Error percentage of prediction in standard PTO speed zone}

Nine sets of the test reports from the OECD CODE 2 were selected to evaluate our data, power and fuel consumption. The range of the error percentage at power prediction was from $0.1 \%$ to $9.54 \%$, and its mean value was $3.28 \%$. The range of the error percentage at fuel consumption was also from $2.05 \%$ to $12.24 \%$, and its mean value was $5.3 \%$.

\section{Prediction of fuel consumption in the non-rated speed zone}

In the non-rated speed zone, fuel consumption data at point from 12 to 16 (Figure 3) was predicted as a function of the speed ratio. A quadratic equation was also applied to model the power and fuel consumption at full load as a function of the speed ratio.

Fuel consumptions were predicted by using the equation (7) developed by Kim et al. (2011).

$$
\begin{aligned}
& Q_{i}=s_{1} n_{c}^{2}+\left(s_{2}-a a_{p}\right) n_{c}+s_{3}+a a_{p} n_{i} \\
& n_{c}=\frac{-\left(k_{2}-a_{p}\right)+\sqrt{\left(k_{2}-a_{p}\right)^{2}-4 k_{1}\left(k_{3}+a_{p} n_{i}-P_{i}\right)}}{2 k_{1}}
\end{aligned}
$$

where, $\mathrm{a}=$ slope of fuel consumption versus power at the points from 1 to 5 in rated speed zone

$\mathrm{a}_{\mathrm{p}}=$ slope of power versus speed ratio at the points from 1 to 5 in rated speed zone

$\mathrm{n}_{\mathrm{i}}=$ ratio of reduced speed $i$ to rated speed.

$\mathrm{n}_{\mathrm{C}}=$ ratio of speed at intersection between speedpower curve at full load and the line passing through any point with slope a

$\mathrm{P}_{\mathrm{i}}=$ engine power at reduced speed $i, \mathrm{~kW}$ $\mathrm{s}_{1}, \mathrm{~S}_{2}, \mathrm{~S}_{3}=$ coefficients of quadratic equation of power as a function of speed ratio for full load

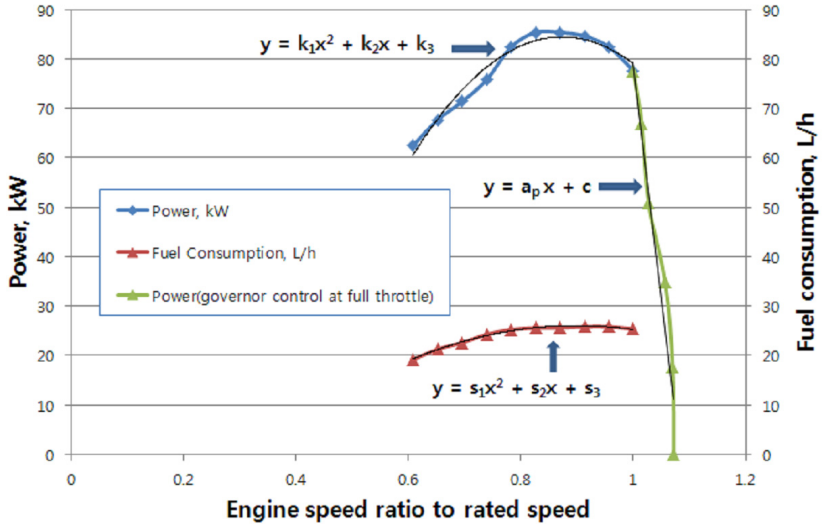

Figure 5. Power and fuel consumption graph as a function of speed ratio at the full load.

\section{$\mathrm{k}_{1}, \mathrm{k}_{2}, \mathrm{k}_{3}=$ coefficients of quadratic equation of fuel consumption as a function of speed ratio for full load}

\section{Classification index, $C_{i}$}

The classification index $C_{i}$ was obtained by integrating the 4 sub-indexes with different weighting factors and is given as

$$
C_{i}=\frac{1}{7}\left(C_{\text {rate }}+2 C_{P T O}+2 C_{P A R T}+2 C_{P U L L}\right)
$$

As $C_{i}$ is the smaller, the energy efficiency becomes the better because $C_{i}$ is specific volumetric fuel consumption.

Weighting factors for $C_{P T O}, C_{P A R T}, C_{P U L L}$ were multiplied by 2 to reflect the actual time of tractor usage in Korea.

In 2010, time used for each operations was shown in Table 4 (RDA, 2011).

From Table 4, the usage time of drawbar is very similar to the value of PTO. It can be inferred that the same weighting factor was applied to PTO and drawbar zone.

In addition, percentage of total power versus the rated power for actual operation is $70 \%$ (Kim et al, 2011).

Table 4. Scope of each grade for 131 tractor models by five-classification system

\begin{tabular}{c|c|c|c} 
& Operation & Usage time per year, \% \\
\hline \multirow{2}{*}{ Drawbar } & transportation & 17.8 & 45.7 \\
& plowing & 16.4 & \\
& leveling & 11.5 & 43.1 \\
\hline \multirow{2}{*}{ PTO } & soil preparation & 30.3 & 11.2 \\
\hline
\end{tabular}




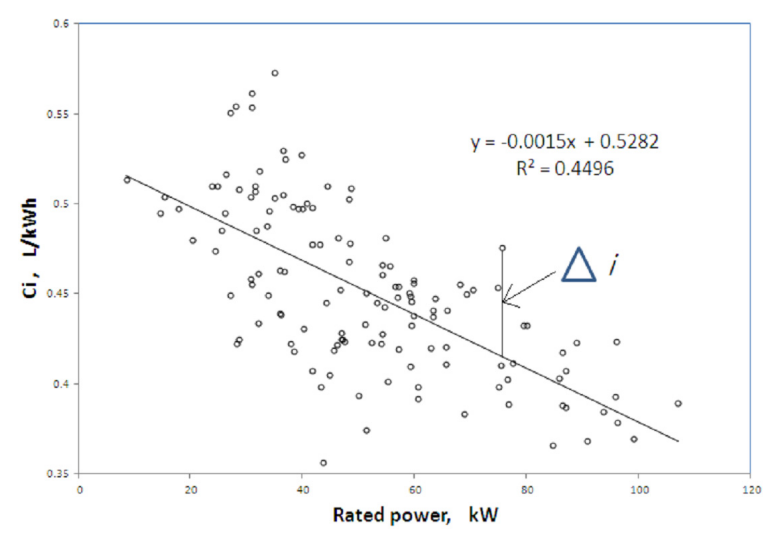

Figure 6. Scatter diagram of classification indexes of 131 tractor models.

Weighting factor of non-rated speed zone can be regarded as 2 .

Because actual operation is under the non-rated speed zone, weighting factors at STD PTO speed, drawbar, and the non-rated speed zone can be regarded as the same.

\section{Classification}

The classification indexes were obtained from 131 tractor models which were tested during the period from 2006 to 2010 in Korea. Since the test was conducted by Korean test method which has different points from OECD, some fuel consumption and power data were predicted for modeling the classification indexes. Figure 6 shows a scatter diagram of the classification indexes plotted as a function of the rated power of the model tractor.

A regression analysis between the classification index and rated power has resulted in a linear equation like equation (9).

$$
C_{\text {avg }}=A \times P_{\text {rate }}+B
$$

where, $P_{\text {rate }}=$ rated power of tractor $(\mathrm{kW})$

$\mathrm{A}=$ slope of regression line $\left(\mathrm{L} / \mathrm{kW}^{2} \mathrm{~h}\right)$

$\mathrm{B}=$ intercept of regression line $(\mathrm{L} / \mathrm{kWh})$

Values of A and B of equation (9) became -0.0015 and 0.5282 respectively.

$\triangle_{i}$ was defined as the difference between the index $C_{i}$ and $C_{a v g}$ for the i-th tractor (Equation (10)).

$$
\triangle_{i}=C_{i}-C_{a v g}
$$

\begin{tabular}{|c|c|}
\hline Grade & Scope \\
\hline 1st & $\triangle_{i}<-0.03517$ \\
\hline 2nd & $-0.03517 \leq \Delta_{i}<-0.01284$ \\
\hline 3rd & $-0.01284 \leq \Delta_{i}<0.013596$ \\
\hline 4th & $0.013596 \leq \Delta_{i}<0.035929$ \\
\hline 5 th & $0.035929 \leq \Delta_{i}$ \\
\hline
\end{tabular}

Table 6. Scope of $C_{i}$ at each grade for 131 tractor models by five-classification system

\begin{tabular}{cc}
\hline Grade & Scope \\
\hline 1st & $C_{i}<-0.0015 P_{\text {rate }}+0.493031$ \\
\hline 2nd & $-0.0015 P_{\text {rate }}+0.493031 \leq C_{i}<-0.0015 P_{\text {rate }}+0.515364$ \\
\hline 3rd & $-0.0015 P_{\text {rate }}+0.515364 \leq C_{i}<-0.0015 P_{\text {rate }}+0.541796$ \\
\hline 4th & $-0.0015 P_{\text {rate }}+0.541796 \leq C_{i}<-0.0015 P_{\text {rate }}+0.564129$ \\
\hline 5th & $-0.0015 P_{\text {rate }}+0.564129 \leq C_{i}$ \\
\hline
\end{tabular}

Average and standard deviation of $\triangle_{i}$ can be obtained by equation (11) and (12) respectively.

$$
\begin{aligned}
& \Delta_{\text {avg }}=\frac{1}{131} \sum_{i=1}^{131} \Delta_{i} \\
& \sigma_{\Delta}=\sqrt{\frac{\sum_{i=1}^{131}\left(\Delta_{i}-\Delta_{a v g}\right)^{2}}{130}}
\end{aligned}
$$

For 131 tractor models, the average $\triangle_{\text {avg }}$ and the standard deviation were obtained as 0.00038 and 0.0343 respectively. $\mathrm{Z}$ was the stochastic variable of the standard normal distribution of random variable $\Delta_{i}$ having average $\Delta_{\text {avg }}$ and standard deviation $\sigma_{\Delta}$, and can be expressed as equation (13) and its mean and variance are 0 and 1 , respectively.

$$
Z=\frac{\triangle_{i}-\Delta_{a v g}}{\sigma_{\triangle}}
$$

Inserting obtained values to $\triangle_{\text {avg }}$ and $\sigma_{\Delta}$, equation (13) becomes equation (14).

$$
Z=\frac{\triangle_{i}-0.00038}{0.0343} \text { or } \triangle_{i}=0.0343 Z+0.00038
$$

The number of classifications can be determined in accordance with tractor manufacturers. In this study, a five-classification system was taken. It was also assumed 


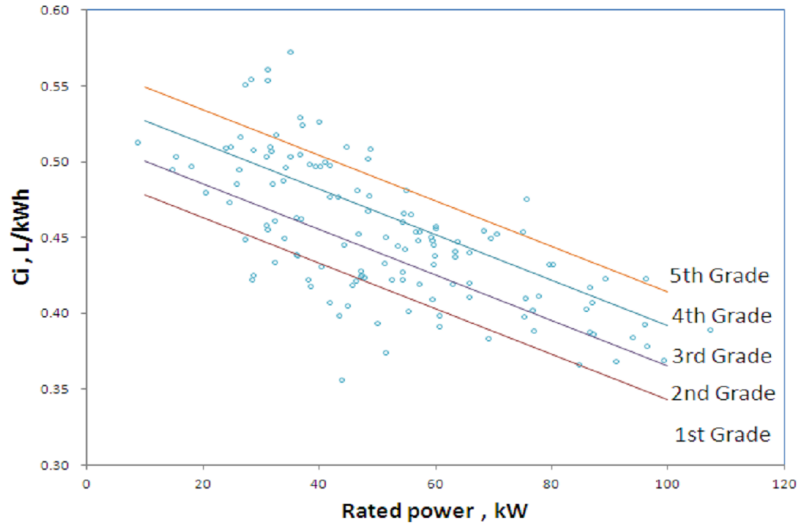

Figure 7. Boundary line of classification grades of 131 tractor models.

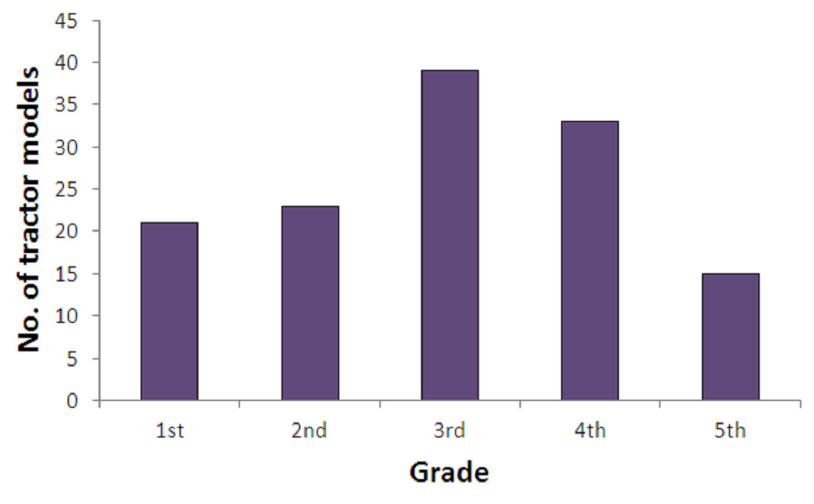

Figure 8. Distribution histogram of tractors by the grades of 131 tractor models.

Table 7. Number and ratio by interval of rated power of models classified by five-classification system for 131 tractor models

\begin{tabular}{|c|c|c|c|c|c|c|c|c|}
\hline \multicolumn{3}{|c|}{ Rated power $<10$} & \multicolumn{3}{|c|}{$10 \leq$ Rated power $<20$} & \multicolumn{3}{|c|}{$20 \leq$ Rated power $<30$} \\
\hline Grade & Q'ty & Ratio (\%) & Grade & Q'ty & Ratio (\%) & Grade & Q'ty & Ratio (\%) \\
\hline 1 & 0 & 0 & 1 & 0 & 0.0 & 1 & 2 & 15.4 \\
\hline 2 & 0 & 0 & 2 & 2 & 66.7 & 2 & 1 & 7.7 \\
\hline 3 & 1 & 100 & 3 & 1 & 33.3 & 3 & 4 & 30.8 \\
\hline 4 & 0 & 0 & 4 & 0 & 0.0 & 4 & 3 & 23.1 \\
\hline 5 & 0 & 0 & 5 & 0 & 0.0 & 5 & 3 & 23.1 \\
\hline Sum & 1 & 100 & Sum & 3 & 100 & Sum & 13 & 100 \\
\hline Grade Avg. & 3 & & Grade Avg. & 2.3 & & Grade Avg. & 3.3 & \\
\hline \multicolumn{3}{|c|}{$30 \leq$ Rated power $<40$} & \multicolumn{3}{|c|}{$40 \leq$ Rated power $<50$} & \multicolumn{3}{|c|}{$50 \leq$ Rated power $<60$} \\
\hline Grade & Q'ty & Ratio(\%) & Grade & Q'ty & Ratio(\%) & Grade & Q'ty & Ratio(\%) \\
\hline 1 & 4 & 14.3 & 1 & 5 & 20 & 1 & 2 & 8 \\
\hline 2 & 4 & 14.3 & 2 & 6 & 24 & 2 & 7 & 28 \\
\hline 3 & 6 & 21.4 & 3 & 5 & 20 & 3 & 9 & 36 \\
\hline 4 & 7 & 25.0 & 4 & 5 & 20 & 4 & 6 & 24 \\
\hline 5 & 7 & 25.0 & 5 & 4 & 16 & 5 & 1 & 4 \\
\hline Sum & 28 & 100 & Sum & 25 & 100 & Sum & 25 & 100 \\
\hline Grade Avg. & 3.3 & & Grade Avg. & 2.9 & & Grade Avg. & 2.9 & \\
\hline
\end{tabular}

\begin{tabular}{|c|c|c|c|c|c|c|c|c|}
\hline \multicolumn{3}{|c|}{$60 \leq$ Rated power $<70$} & \multicolumn{3}{|c|}{$70 \leq$ Rated power $<80$} & \multicolumn{3}{|c|}{$80 \leq$ Rated power $<90$} \\
\hline Grade & Q'ty & Ratio(\%) & Grade & Q'ty & Ratio(\%) & Grade & Q'ty & Ratio(\%) \\
\hline 1 & 3 & 25.0 & 1 & 0 & 0.0 & 1 & 0 & 0 \\
\hline 2 & 5 & 41.7 & 2 & 1 & 11.1 & 2 & 0 & 0 \\
\hline 3 & 3 & 25.0 & 3 & 4 & 44.4 & 3 & 5 & 62.5 \\
\hline 4 & 1 & 8.3 & 4 & 1 & 11.1 & 4 & 2 & 25 \\
\hline 5 & 0 & 0.0 & 5 & 3 & 33.3 & 5 & 1 & 12.5 \\
\hline Sum & 12 & 100 & Sum & 9 & 100 & Sum & 8 & 100 \\
\hline Grade Avg. & 2.2 & & Grade Avg. & 3.7 & & Grade Avg. & 3.5 & \\
\hline
\end{tabular}

\begin{tabular}{cccccc}
\hline \multicolumn{2}{c}{$m 90 \leq$ Rated power $<100$} & \multicolumn{3}{c}{$100 \leq$ Rated power $<110$} \\
Grade & Q'ty & Ratio(\%) & Grade & Q'ty & Ratio(\%) \\
\hline 1 & 1 & 16.7 & 1 & 0 & 0 \\
2 & 1 & 16.7 & 2 & 0 & 0 \\
3 & 2 & 33.3 & 3 & 1 & 100 \\
4 & 2 & 33.3 & 4 & 0 & 0 \\
5 & 0 & 0.0 & 5 & 0 & 0 \\
Sum & 6 & 100 & Sum & 1 & 100 \\
Grade Avg. & 2.8 & & Grade Avg. & 3 & \\
\hline
\end{tabular}




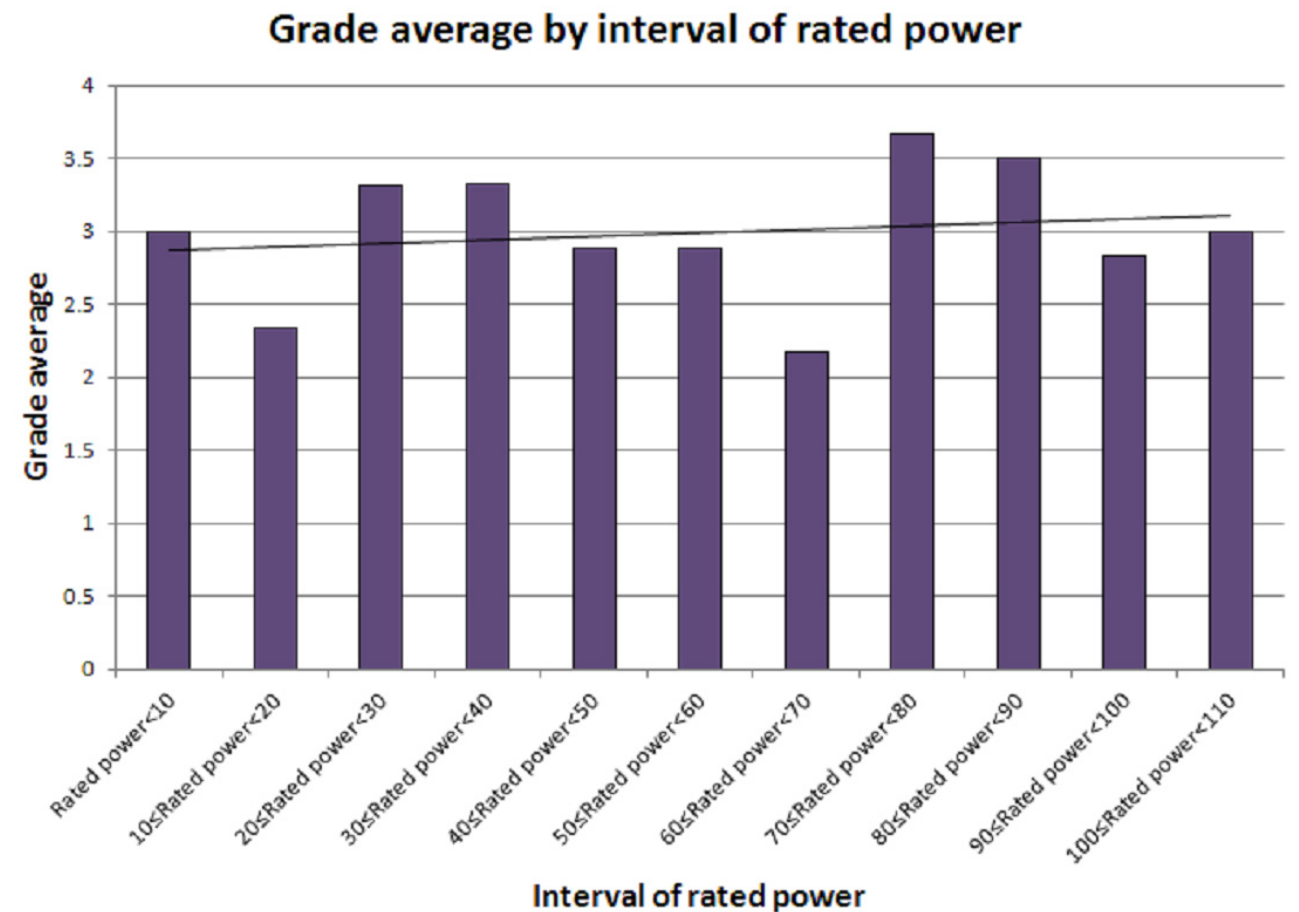

Figure 9. Grade average of classified tractors by rated power of 131 tractor models.

\begin{tabular}{|c|c|c|c|c|c|c|c|c|}
\hline \multicolumn{3}{|c|}{2006} & \multicolumn{3}{|c|}{2007} & \multicolumn{3}{|c|}{2008} \\
\hline Grade & Q'ty & Ratio(\%) & Grade & Q'ty & Ratio(\%) & Grade & Q'ty & Ratio(\%) \\
\hline 1 & 2 & 13.3 & 1 & 2 & 5.6 & 1 & 4 & 13.8 \\
\hline 2 & 3 & 20.0 & 2 & 3 & 8.3 & 2 & 9 & 31.0 \\
\hline 3 & 3 & 20.0 & 3 & 15 & 41.7 & 3 & 6 & 20.7 \\
\hline 4 & 5 & 33.3 & 4 & 10 & 27.8 & 4 & 6 & 20.7 \\
\hline 5 & 2 & 13.3 & 5 & 6 & 16.7 & 5 & 4 & 13.8 \\
\hline Sum & 15 & 100 & Sum & 36 & 100 & Sum & 29 & 100 \\
\hline \multirow[t]{2}{*}{ Grade Avg. } & 3.133333 & & Grade Avg. & 3.416667 & & Grade Avg. & 2.896552 & \\
\hline & 2009 & & & 2010 & & & & \\
\hline Grade & Q'ty & Ratio(\%) & Grade & Q'ty & Ratio(\%) & & & \\
\hline 1 & 4 & 12.1 & 1 & 9 & 50 & & & \\
\hline 2 & 7 & 21.2 & 2 & 1 & 5.6 & & & \\
\hline 3 & 12 & 36.4 & 3 & 3 & 16.7 & & & \\
\hline 4 & 8 & 24.2 & 4 & 4 & 22.2 & & & \\
\hline 5 & 2 & 6.1 & 5 & 1 & 5.6 & & & \\
\hline Sum & 33 & 100 & Sum & 18 & 100 & & & \\
\hline Grade Avg. & 2.909091 & & Grade Avg. & 2.277778 & & & & \\
\hline
\end{tabular}

that percentage distribution over the five classification was $15 \%$ for the first, $20 \%$ for the second, $30 \%$ for the third, $20 \%$ for the fourth and $15 \%$ for the fifth grades. Based on this classification, the $\mathrm{Z}$ value for each grade was obtained from a statistical table (Kim et al, 2010). Substituting the $\mathrm{Z}$ values into equation (13) and solving for $\Delta_{i}$ for each grade yields scopes like Table 5 .

$\triangle_{i}$ was substituted into equation (9) and (10) to calculate $C_{i}$ subsequently, Table 6 shows the conversion of Table 5.

\section{Results and Discussion}

131 tractor models in Korea were classified by energy efficiency with the developed indexes. Figure 7 shows the 


\section{Grade average by year}

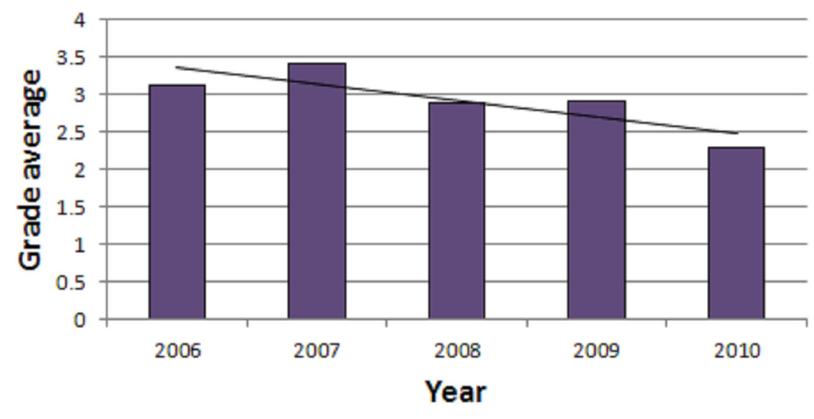

Figure 10. Grade average of classified tractors by year of 131 tractor models.

Table 9. Number and ratio of models by area of product classified by five-classification system for 131 tractor models

\begin{tabular}{|ccc|}
\hline & Domestic & \\
Grade & Q'ty & Ratio, \% \\
\hline 1 & 19 & 19 \\
2 & 16 & 16 \\
\hline 3 & 27 & 27 \\
4 & 27 & 27 \\
\hline 5 & 11 & 11 \\
\hline Sum & 100 & 100 \\
\hline Grade Avg. & 3.0 & \\
\hline & & \\
\hline Grade & Qmport & 6.5 \\
\hline 1 & 2 & 22.6 \\
\hline 2 & 7 & 38.7 \\
\hline 3 & 12 & 19.4 \\
\hline 4 & 6 & 12.9 \\
\hline 5 & 4 & 100 \\
\hline Sum & 31 & \\
\hline Grade Avg. & 3.1 & \\
\hline
\end{tabular}

boundary of each grade of 131 tractor models classified by the five-classification system.

As the rated power is the bigger, an energy efficiency becomes the better (Figure 7).

Figure 8 shows distribution of 131 tractor models classified by the classification grades. Although the distribution is not exactly the same as intended, it is acceptable for a reasonable classification.

After classifying by energy efficiency, the classified models were sorted by a several criterion.

At first, 131 tractor models were sorted by rated powers. Number and ratio of models sorted by rated powers were shown in Table 7.

Grade average of models sorted by rated powers was shown in Figure 9. Generally, an energy efficiency becomes better as the rated power grows. However, it was not clear in our case, because of lack of data set.

Next, 131 tractor models were sorted by year, and their number and ratios were shown in Table 8.

Grade average of models was sorted by year (Figure 10). An energy-saving technology has taken effect over years.

Finally, 131 tractor models were sorted by area of product (Table 9). Domestic tractor models were more energy efficient than the imported tractor models by 0.06 in grade average.

\section{Summary and Conclusions}

This study was conducted to classify the energy efficiency of 131 tractor models produced from 2006 to 2010 in an authorized testing institution of South Korea. Four sub-indexes were developed using the fuel consumptions at $60 \%$ and $90 \%$ of rated speed with partial loads and at pull speeds of $3.0 \mathrm{~km} / \mathrm{h}$ and $7.5 \mathrm{~km} / \mathrm{h}$ with maximum drawbar pull. Weighting factors of the sub-indexes were also considered to reflect the characteristics of tractor's actual working hours in Korea. Four sub-indexes were integrated into a classification index. Using the developed classification index, a five-classification system was made on the basis of normal distribution of tractors over the classification range. Followings are conclusions of this study.

(1) The test result 131 tractor models produced from 2006 to 2010 were used to develop the classification index by energy efficiency.

(2) When fuel consumption data are not available at the standard PTO speed with varying load, a prediction method was adopted to supplement those data. proposed. At partial load at $60 \%$ and $90 \%$ of rated speed with partial load, the fuel consumption data at each operational point was predicted by another prediction model(Kim et al, 2011).

(3) Methods were proposed for the development of a classification index with four sub-indexes. A fiveclassification system(Kim et al., 2010) based on the normal distribution of classified tractors was carried out.

(4) Five-classification distribution of tractors can be used to rate tractors by energy efficiency. 


\section{Conflict of Interest}

No potential conflict of interest relevant to this article was reported.

\section{Acknowledgements}

This work was carried out with the support of the Rural Development Administration funded by the Korean Government (PJ907126)

\section{References}

Gil-Sierra, J., J. Ortiz-Cañavate, V. Gil-Quirós and J. Casanova. 2007. Energy efficiency in agricultural tractors: A methodology for their classification. Applied Engineering in Agriculture 23(2):145-150.

Kim, S. C., K. U. Kim. 2010. Modeling of Fuel Consumption Rate for Agricultural Tractors. Journal of Biosystems Engineering 35(1):1-9. (In Korean)

Kim, S. C., K. U. Kim. 2010. Rating Agricultural Tractors by Fuel Efficiency. Journal of Biosystems Engineering 35(2):69-75. (In Korean)

Kim, S. C., K. U. Kim and D. C. Kim. 2011. Prediction of fuel consumption of agricultural tractors. Applied Engineering in Agriculture 27(5):705-709.

Kim, W. C., J. J. Kim, B. W. Park, S. H. Park, M. S. Song, S. Y.
Lee, Y. C. Lee, J. W. Jeon and S. S. Cho. 2010. General Statics. Youngji Publishers.

Kim, Y. J., S. O. Chung, S. J. Park and C. H. Choi. 2011. Analysis of Power Requirement of Agricultural Tractor by Major Field Operation. Journal of Biosystems Engineering 36(2):79-88. (In Korean)

Korea Agricultural Machinery Industry Cooperative, Korean Society for Agricultural Machinery. 2010. Agricultural Machinery Yearbook Republic of Korea.

Ministry for Food, Agriculture, Forestry and Fisheries. 2011. Ownership of Agricultural Machinery at 2011. Available at: http://www.mifaff.go.kr

OECD. 2009. Draft summary record of the technical working group on updating the tractor code. TAD/ CA/T/M(2009)2. Paris, France.

OECD. 2012. Energy efficiency classification of agricultural tractors in Turkey based on OECD tests. TAD/CA/T/ WD(2012)1. Paris, France.

OECD. 2012. OECD Standard Code for the Official Testing of Agricultural and Forestry Tractor Performance Code 2. Paris, France.

Rural Development Administration. 2011. Agricultural Machinery Utilization and agricultural work machine rate. ISBN: 978-89-480-1322-1 93520. Available at: http://lib.rda.go.kr

Shin, C. S. and K. U. Kim. 2012. Development of fuel consumption index for rating agricultural tractors by energy efficiency. Proceedings of the KSAM 2012 Winter Conference 17(1):136-139. 